\title{
Evaluation of aqueous extracts of Taraxacum officinale on growth and invasion of breast and prostate cancer cells
}

\author{
SOPHIA C. SIGSTEDT ${ }^{1}$, CARLA J. HOOTEN ${ }^{1}$, MANIKA C. CALLEWAERT ${ }^{1}$, AARON R. JENKINS ${ }^{1}$, \\ ANNTHERESE E. ROMERO ${ }^{1}$, MICHAEL J. PULLIN ${ }^{2}$, ALEXANDER KORNIENKO ${ }^{3}$, \\ TIMOTHY K. LOWREY ${ }^{4}$, SEVERINE VAN SLAMBROUCK ${ }^{*}$ and WIM F.A. STEELANT ${ }^{1 *}$ \\ Laboratories of ${ }^{1}$ Biochemical and Biomedical Research, ${ }^{2}$ Aqueous Environmental Chemistry, \\ and ${ }^{3}$ Synthetic Organic and Medicinal Chemistry, Department of Chemistry, New Mexico Tech, Socorro, NM; \\ ${ }^{4}$ UNM Herbarium, Museum of Southwestern Biology, University of New Mexico, Albuquerque, NM, USA
}

Received December 4, 2007; Accepted January 25, 2008

\begin{abstract}
Ethnotraditional use of plant-derived natural products plays a significant role in the discovery and development of potential medicinal agents. Plants of the genus Taraxacum, commonly known as dandelions, have a history of use in Chinese, Arabian and Native American traditional medicine, to treat a variety of diseases including cancer. To date, however, very few studies have been reported on the anti-carcinogenic activity of Taraxacum officinale (TO). In the present study, three aqueous extracts were prepared from the mature leaves, flowers and roots, and investigated on tumor progression related processes such as proliferation and invasion. Our results show that the crude extract of dandelion leaf (DLE) decreased the growth of MCF-7/AZ breast cancer cells in an ERK-dependent manner, whereas the aqueous extracts of dandelion flower (DFE) and root (DRE) had no effect on the growth of either cell line. Furthermore, DRE was found to block invasion of MCF-7/ AZ breast cancer cells while DLE blocked the invasion of LNCaP prostate cancer cells, into collagen type I. Inhibition of invasion was further evidenced by decreased phosphorylation levels of FAK and src as well as reduced
\end{abstract}

Correspondence to: Professor Wim F.A. Steelant, Department of Chemistry, Laboratory of Biochemical and Biomedical Research, New Mexico Tech, 801 Leroy Place, Socorro, NM 87801, USA

E-mail: steelant@nmt.edu

${ }^{*}$ Contributed equally

Abbreviations: TO, Taraxacum officinale; DFE, dandelion flower extract; DLE, dandelion leaf extract; DRE, dandelion root extract; ERK 1/2, extracellular signal-regulated kinase 1 and 2; FAK, focal adhesion kinase; MAPK, mitogen-activated protein kinase; MMP, matrix metalloproteinase; O.D., optical density; SRB, sulforhodamine B

Key words: Taraxacum officinale, breast cancer, prostate cancer, growth, invasion activities of matrix metalloproteinases, MMP-2 and MMP-9. This study provides new scientific data on TO and suggests that TO extracts or individual components present in the extracts may be of value as novel anti-cancer agents.

\section{Introduction}

Plants of the genus Taraxacum, also known as dandelions, are members of the Asteraceae family. These perennial plants are widespread throughout the warmer temperate zones of the Northern Hemisphere and have been used for centuries as a remedy for various ailments by several societies. Dandelions play a pivotal role in traditional Chinese medicine (TCM) and are frequently used for treatment of breast, uterine and lung tumors as well as hepatitis and digestive diseases $(1,2)$, while Native Americans use dandelion roots and herbs to treat kidney disease, dyspepsia and heartburn. In traditional Arabian medicine, dandelions have been applied to remedy liver and spleen disorders (3), whereas European herbalists authorize the use of dandelions for fever, boils, eye problems, diabetes and diarrhea (4).

The variety of health benefits associated with the use of dandelions has been attributed to specific Taraxacum species as extracts of the whole plants or specific plant parts. Anticarcinogenic activities have been reported for the aqueous root extract of Taraxacum japonicum on mouse skin tumors (5). Further study revealed that taraxasterol and taraxerol, triterpenoids isolated from $T$. japonicum, were responsible for the observed effect on mouse skin tumors and that taraxasterol inhibited spontaneous mammary carcinogenesis, after oral administration (6). Taraxinic acid, isolated from Taraxacum coreanum showed potent antiproliferative activity against HL-60 cells (7) and the ethanolic extracts of the Chinese dandelion root (Taraxacum mongolicum) inhibited the growth of B16 2F2 mouse melanoma cells (8). Antitumor action has also been demonstrated for aqueous Taraxacum officinale (TO) extracts, through TNF- $\alpha$ and IL-1 $\alpha$ secretion in HeP G2 cells (9).

Based on the limited availability of scientific data on the effect of Taraxacum species on human breast cancer and the claims of the use of the common dandelion, Taraxacum 
Table I. \%Yield obtained after cold aqueous extraction of $75 \mathrm{~g}$ of dried plant material.

\begin{tabular}{lccc}
\hline Taraxacum officinale & Before $(\mathrm{g})$ & After $(\mathrm{g})$ & \% Yield \\
\hline Flowers & 75 & 6 & 8 \\
Leaves & 75 & 8 & 11 \\
Roots & 75 & 12 & 16 \\
\hline
\end{tabular}

officinale, to treat prostate cancer, we examined whether dried aqueous extracts of various parts of Taraxacum officinale have an effect on MCF-7/AZ breast and LNCaP C4-2B prostate cancer cells. In the current, study we have analyzed the impact of the different TO extracts on proliferation and metastasis related properties.

This study demonstrates a number of previously unknown effects of Taraxacum officinale on human cancer cells and suggests that TO extracts or individual components present in the extracts may be of value as novel anti-cancer agents.

\section{Materials and methods}

Plant materials and preparation of extracts. Plant materials of Taraxacum officinale were obtained from local herb stores. Voucher samples are archived in the laboratory and are available for analysis by contacting the corresponding author. The cold aqueous extracts were prepared as follows: $75 \mathrm{~g}$ of the dried plant parts were soaked in water for $24 \mathrm{~h}$ at room temperature. The mixtures were filtered to remove particulate matter, lyophilized and the resulting powders were stored in a desiccator at $4^{\circ} \mathrm{C}$. Table I shows the yields obtained from the different parts.

Antibodies and other reagents. Antibodies directed to p-FAK (Tyr397) and p-src (Tyr418) were from Invitrogen (Carlsbad, CA). Mouse anti-FAK and anti-src monoclonal antibodies $(\mathrm{mAb})$ were from Transduction Laboratories (San Jose, CA). Rabbit anti-ERK and anti-p-ERK (Thr202/Tyr204) were obtained from Cell Signaling Technologies (Beverly, MA). Secondary biotinylated anti-rabbit and anti-mouse Abs and Vectastain ${ }^{\circledR}$ ABC-AmP ${ }^{\text {Tм }}$ kit were from Vector Laboratories (Burlingame, CA). ET-18-OMe (clinical grade) was kindly provided by Dr P. Hilgard (ASTA Medica, Frankfurt am Main, Germany). Drug toxicity was evaluated through measurement of mitochondrial dehydrogenase activities with MTT reagent (Sigma, St. Louis, MO) (10). BCA (bicinchoninic acid) protein assay reagent kit was from Pierce Biotechnology (Rockford, IL).

Cell culture. MCF-7/AZ is a variant of the human mammary carcinoma cell family MCF-7 (11). The cells were maintained at $37^{\circ} \mathrm{C}$ in a mixture of Dulbecco's modified Eagle's medium (DMEM) and HAMF12 (50/50) supplemented with $100 \mathrm{IU} / \mathrm{ml}$ penicillin, $100 \mu \mathrm{g} / \mathrm{ml}$ streptomycin and $10 \%$ fetal bovine serum (FBS) (Invitrogen), in a humidified atmosphere containing $10 \% \mathrm{CO}_{2}$. The metastatic prostate cancer subline LNCaP
C4-2B $(12,13)$ was grown in RPMI-medium supplemented with 5\% FBS, $100 \mathrm{IU} / \mathrm{ml}$ penicillin, $100 \mu \mathrm{g} / \mathrm{ml}$ streptomycin (Invitrogen) at $37^{\circ} \mathrm{C}$ in a humidified atmosphere containing $5 \% \mathrm{CO}_{2}$.

Assay for cell viability. Cell viability was tested in accordance with Romijn et al (10). Briefly, mitochondrial dehydrogenase activities were measured by an MTT-reagent (Sigma). Cells were seeded in microtiter plates at an initial density of $1.5 \times 10^{4}$ cells in $200 \mu 1$ culture medium and treated with increasing concentrations of each TO extract. In each experiment, eight wells were used to determine the mean O.D. referring to cell viability.

\section{Assays for cell growth}

Sulforhodamine B assay. Cells were seeded in microtiter plates at an initial density of $1.5 \times 10^{4}$ cells in $200 \mu 1$ culture medium and treated with increasing concentrations of each TO extract. After an incubation period of 4 days, the amount of cell protein in each well was estimated with the sulforhodamine B assay (SRB) (Sigma) (14).

Cell counting. Cells were seeded in $25-\mathrm{cm}^{2}$ culture flasks at a density of $1.5 \times 10^{5}$ cells in $5 \mathrm{ml}$. The cells were grown in the presence or absence of the crude aqueous TO extracts for 4 days, and counted with a hemacytometer (Hausser Scientific, Horsham, PA).

Collagen type I invasion assay. Six-well plates were filled with $1.25 \mathrm{ml}$ neutralized type I collagen $(0.09 \%$, Millipore, Billerica, MA) and incubated for $1 \mathrm{~h}$ at $37^{\circ} \mathrm{C}$ to allow gelification. For invasion into collagen type I gels, non-invasive MCF-7/AZ cells, pretreated with ET-18-OMe for $24 \mathrm{~h}$ to become invasive into collagen type I (15) and LNCaP C4-2B cells, were harvested using Moscona buffer and trypsin/EDTA and seeded on top of collagen type I gels. Cultures were incubated for $24 \mathrm{~h}$ at $37^{\circ} \mathrm{C}$ in the presence or absence of the different TO extracts. Numbers of cells penetrating into the gel or remaining at the surface were counted, using an inverted microscope and expressed as the invasion index, being the percentage of invading cells over the total number of cells (16).

Western blotting. Cell lysates were made from $70 \%$ confluent cultures. Cells were treated for the indicated times with the crude aqueous TO extracts, washed and lysed in $0.5 \mathrm{ml}$ lysis buffer containing $1 \%$ Triton X-100, 1\% NP-40 and the following inhibitors: aprotinin $(10 \mu \mathrm{g} / \mathrm{ml})$, leupeptin $(10 \mu \mathrm{g} / \mathrm{ml})$, PMSF (1.72 mM), NaF (100 mM), $\mathrm{NaVO}_{3}(500 \mu \mathrm{M})$ and $\mathrm{Na}_{4} \mathrm{P}_{2} \mathrm{O}_{7}(500 \mu \mathrm{g} / \mathrm{ml})$. Aliquots of lysates containing the same quantity of proteins were boiled for $5 \mathrm{~min}$ in SDS-PAGE sample buffer supplemented with 5\% B-mercaptoethanol, electrophoresed on $7.5 \%$ SDS-PAGE and transferred to PVDF membranes (Immobilon-P, Bio-Rad Laboratories, Hercules, $\mathrm{CA})$. After transfer, membranes were incubated with relevant antibodies vs p-FAK, p-src and p-ERK followed by incubation with a secondary biotinylated antibody and developed by ECL, using the Vectastain ${ }^{\circledR} \mathrm{ABC}-\mathrm{AmP}^{\mathrm{TM}}$ detection kit. The membranes were stripped at $50^{\circ} \mathrm{C}$ for $30 \mathrm{~min}$ in $100 \mathrm{mM}$ $\beta$-mercaptoethanol, 2\% SDS, $62.5 \mathrm{mM}$ Tris- $\mathrm{HCl}$ (pH 6.8), 
Table II. O.D. ${ }_{80}$ values for each crude aqueous TO extract as determined by MTT assay after $24 \mathrm{~h}$ exposure.

\begin{tabular}{lcc}
\hline Taraxacum officinale & MCF-7/AZ & LNCaP C4-2B \\
O.D.80 values $(\mu \mathrm{g} / \mathrm{ml})$ & & \\
\hline Flowers & $>500$ & 30 \\
Leaves & 60 & 60 \\
Roots & 20 & 10 \\
\hline
\end{tabular}

and reblotted with Abs against FAK, src and ERK. Images of the membranes were created and analyzed on the BioChemi System and analysis software (UVP, Upland, CA).

In-gel gelatinase assay. Gelatin zymography was performed as described (17). Subconfluent MCF-7/AZ cells, pretreated with ET-18-OMe, or LNCaP C4-2B cells were incubated with the different extracts in serum-free medium for 6,12 and $18 \mathrm{~h}$ at $37^{\circ} \mathrm{C}$. The medium was collected, clarified by centrifugation, resolved in non-reducing gels containing gelatin $(1.5 \mathrm{mg} / \mathrm{ml})$ and processed for identification of gelatinase activity.

Statistics. All treatments were matched and carried out at least 3 times. Data were analyzed using Excel, for determination of mean, SD and Student's t-test (95\%). Intensity of the immunoblotted bands was quantified by densitometry, using statistical software Scion Image (Scion Corporation, Frederick, MD).

\section{Results}

Effect of Taraxacum officinale extracts on cell viability. MCF-7/AZ breast cancer cells and LNCaP C4-2B prostate cancer cells were exposed to increasing concentrations of DFE, DLE and DRE for $24 \mathrm{~h}$. The MCF-7/AZ cell viability was unaffected $(98.2 \pm 1.4 \%)$ by the extract of the flower at concentrations up to $500 \mu \mathrm{g} / \mathrm{ml}$, while the percentage of living LNCaP C4-2B cells significantly dropped to $60.5 \pm 2.1 \%$ at $50 \mu \mathrm{g} / \mathrm{ml}$. The extracts of the flower and the root equally affected both cell lines, with DRE being more toxic than DLE, leaving only $50 \%$ viable at a concentration of $50 \mu \mathrm{g} / \mathrm{ml}$ as compared to $180 \mu \mathrm{g} / \mathrm{ml}$ of the leaf extract (data not shown). For further experiments O.D.80 values were used, leaving approximately $80 \%$ of the cells viable (Table II).

Inhibition of ERK and cell growth in human breast cancer cells. The aqueous DLE markedly inhibited the growth of MCF-7/AZ breast cancer cells, by $40 \%$, after $96 \mathrm{~h}$ treatment and this in a concentration-dependent manner (Fig. 1A and B), while no significant effect could be observed on the growth of LNCaP C4-2B cells. DFE and DRE did not affect the growth of either cell line (Fig. 1A). As shown in Fig. 1C, exposure of MCF-7/AZ cells to DLE resulted in a timedependent decrease of ERK activities as compared to untreated
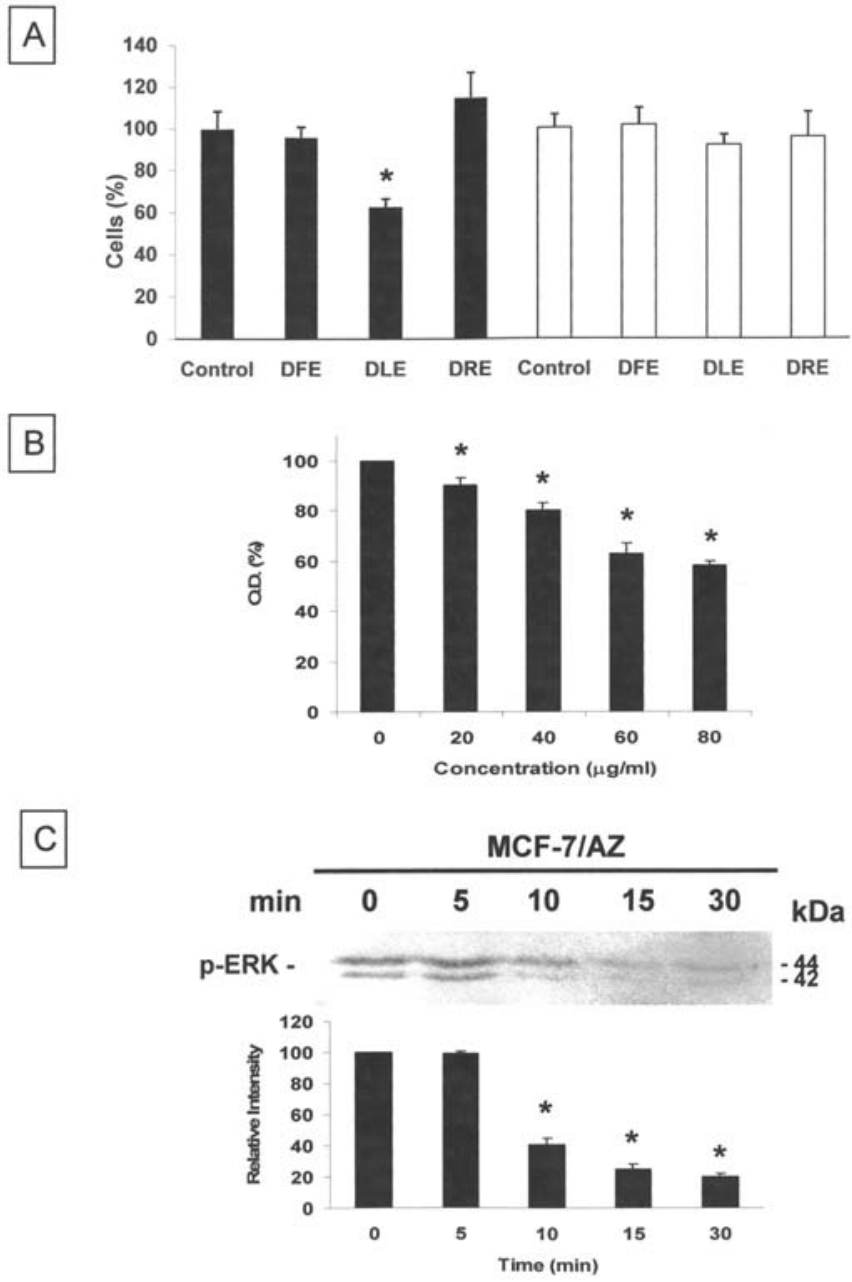

Figure 1. Inhibition of ERK and cell growth in human breast cancer cells. (A) MCF-7/AZ breast cancer cells (black columns) and LNCaP C4-2B prostate cancer cells (white columns) were exposed to DFE, DLE and DRE at their respective O.D. ${ }_{80}$ values for 4 days, and the number of cells was determined by counting and expressed as percentage of control cells. (B) MCF-7/AZ cells were exposed to increasing concentrations of DLE for 4 days and the amount of cellular protein was measured with the Sulforhodamine B assay and expressed as O.D. (\%). (C) Western blot analysis of phosphorylated (activated) ERK $1 / 2$ in MCF-7/AZ breast cancer cells when exposed to DLE $(60 \mu \mathrm{g} / \mathrm{ml})$ for indicated times. Whole cell lysates, containing $25 \mu \mathrm{g}$ of protein, were analyzed by $7.5 \%$ SDS-PAGE and immunoblotted with antibody against activated ERK (p-ERK, Thr202/Tyr204). The membranes were stripped at $50^{\circ} \mathrm{C}$ for $30 \mathrm{~min}$ in stripping buffer $(100 \mathrm{mM}$ ß-mercaptoethanol, $2 \%$ SDS, $62.5 \mathrm{mM}$ Tris- $\mathrm{HCl} \mathrm{pH}$ 6.8) and reblotted with anti-ERK (data not shown). Scion image densitometry analysis of bands of p-ERK, expressed as percentage of total protein in unexposed cells. Bars and flags indicate mean values and standard deviations from three independent experiments. Asterisks indicate statistical difference from controls.

controls, whereas no changes in phosphorylation levels of ERK were observed when cells were exposed to DFE and DRE (data not shown). Total levels of ERK were unaltered upon exposure (data not shown).

Anti-invasive effect of Taraxacum officinale extracts. MCF-7/ AZ breast cancer cells, pretreated with ET-18-OMe (15), and $\mathrm{LNCaP} \mathrm{C} 4-2 \mathrm{~B}$ prostate cancer cells are invasive into collagen type I layer. DRE blocked the induced invasion of MCF-7/AZ cells into collagen type I gel layer, while DFE and DLE had no effect on the invasive behavior of 


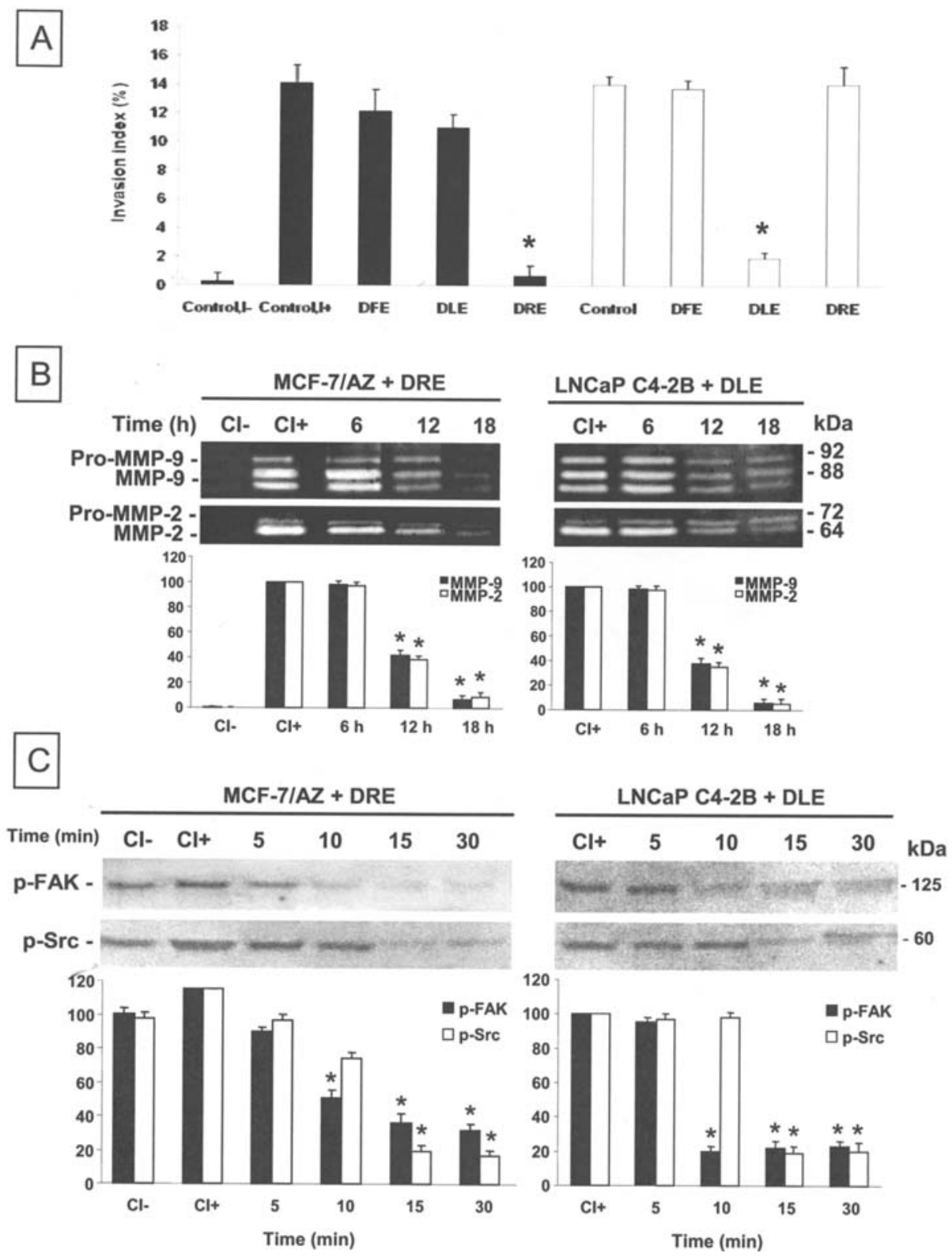

Figure 2. Anti-invasive effect of Taraxacum officinale extracts. (A) Cell suspensions of ET-18-OMe-induced invasive MCF-7/AZ breast cancer cells (black columns) and LNCaP C4-2B prostate cancer cells (white columns) were seeded on top of collagen type I gel, exposed to the different aqueous TO extracts, according to the O.D. ${ }_{80}$ values and cultured at $37^{\circ} \mathrm{C}$ for $24 \mathrm{~h}$. The invasion index expresses the percentage of invading cells into collagen type I over the total number of cells. Controls included untreated MCF-7/AZ cells (Control, I-), ET-18-OMe treated (invasive) MCF-7/AZ cells (Control, I+) and LNCaP C4-2B cells. (B) Activity of MMP-2 and MMP-9 metalloproteinases by gelatin zymography in invasive MCF-7/AZ cells (left panel) and LNCaP C4-2B cells (right panel) when exposed to DRE (20 $\mu \mathrm{g} / \mathrm{ml})$ and DLE $(60 \mu \mathrm{g} / \mathrm{ml})$ for indicated times. Conditioned media prepared from subconfluent cultures were collected, resolved in non-reducing gels containing gelatin $(2 \mathrm{mg} / \mathrm{ml})$ and processed for zones of gel degradation activity. The results are presented as percentage of the activity in invasive control cells (CI+). (C) Western blot analysis of phosphorylated (activated) FAK (p-FAK) and src (p-src) in invasive MCF-7/AZ (left panel) and LNCaP C4-2B (right panel) cells when incubated with DRE $(20 \mu \mathrm{g} / \mathrm{ml})$ and DLE $(60 \mu \mathrm{g} / \mathrm{ml})$ for indicated times. Whole cell lysates, containing $25 \mu \mathrm{g}$ of protein, were analyzed by 7.5\% SDS-PAGE and immunoblotted with antibody against activated FAK (Tyr397) and src (Tyr418). The membranes were stripped at $50^{\circ} \mathrm{C}$ for $30 \mathrm{~min}$ in stripping buffer $(100 \mathrm{mM} \mathrm{B}$-mercaptoethanol, $2 \% \mathrm{SDS}, 62.5 \mathrm{mM}$ Tris- $\mathrm{HCl} \mathrm{pH} \mathrm{6.8)}$ and reblotted with anti-FAK and antisrc (data not shown). Scion image densitometry analysis of bands of p-FAK and p-src expressed as percentage of total protein in invasive cells. Bars and flags indicate mean values and standard deviations from three independent experiments. Asterisks indicate statistical difference from controls.

MCF-7/AZ cells (Fig. 2A). Invasion of LNCaP C4-2B cells into collagen type I gel could be blocked by treatment with DLE and not by DFE and DRE treatment. Further evidence for the anti-invasive effect of DRE and DLE is shown in Fig. 2B, demonstrating decreased activity levels of both MMP-2 and MMP-9. These observations were found to be mediated through the rapid (5-10 min) inhibition of the elevated activity levels of both FAK and src (Fig. 2C). No changes in activity levels of MMPs and FAK and src were detected for the extracts that did not influence invasion (data not shown).

\section{Discussion}

Medicinal herbs and plants continue to play a significant role in drug discovery and development, particularly in cancer research. The overwhelming contribution of natural products to the expansion of the chemotherapeutic arsenal 
is evidenced by the fact that $50 \%$ of all the anticancer drugs approved worldwide between 1940 and 2006 were either natural products or natural product derived (18). Many of these novel anticancer agents have a history of use in traditional medicine, notably in TCM. The most prominent among them are: i) camptothecin, isolated from the Chinese 'happy tree' Camptotheca acuminata (19); ii) podophyllotoxin from Podophyllum peltatum, originally used by Native Americans but also found in large amounts in Podophyllum emodi var. Chinense (20); and iii) paclitaxel initially obtained from Taxus brevifolia and present in high quantities in Taxus chinensis (21).

Although plants of the genus Taraxacum, including Taraxacum officinale, are often used in TCM for the treatment of cancer and there is anecdotal information on the anticancer activity of TO, scientific evidence to support this effect, is lacking. In the present study, we showed that the aqueous DLE significantly reduced the growth of MCF-7/AZ breast cancer cells, in a dose-dependent manner that was not due to its direct cytotoxicity, as analyzed by the MTT assay. DLE did not influence the growth of LNCaP C4-2B prostate cancer cells neither did similarly prepared aqueous extracts from the root and the flower. Additionally, the effect on cell proliferation could be ascribed to the inhibition of ERK activity, with ERK being a major determinant in the MAPK-pathway involved in cell survival, differentiation and cell growth (22). Inhibition of tumor cell proliferation by Taraxacum extracts has been reported earlier and was found to be due to triterpenoids and sesquiterpenes $(5,6)$. Since these compounds are also present in the roots, and no effect of DRE was observed on the growth of either cell line, our results suggest that the inhibitory effect may result from phenolic compounds as dandelion leaves are characterized by higher polyphenolic acids and flavonoid contents (23). This is further supported by several studies that describe the effect of the latter compounds, in particular polyphenols on cancer cell proliferation (24).

The invasive behavior of tumor cells is another important phenomenon affected by the different TO extracts. As demonstrated by the collagen type I invasion assay, DLE inhibits the invasiveness of LNCaP C4-2B cells, while no effect could be observed on the invasion of MCF-7/AZ cells. In addition, we found that extracts of the dandelion root inhibited the invasive behavior of MCF-7/AZ, but not of LNCaP C4-2B cancer cells. This effect was clearly observed after $24 \mathrm{~h}$ and was not due to reduced growth of the particular cancer cells. The inhibitory effect of DLE and DRE on the invasiveness of LNCaP C4-2B and MCF-7/AZ cells, respectively, was further evidenced by zymographic analysis, revealing that DLE and DRE inhibit the gelatinolytic activity of MMP-2 and MMP-9, given that the enzymatic activities of these matrix metalloproteinases correlate with tumorigenicity and metastatic ability of tumor cells (25). Moreover, signal transducers FAK and src, contribute to the secretion of matrix metalloproteinases 2 and 9, and activity levels are found elevated in invasive MCF-7/AZ cells (26) and in LNCaP C4$2 \mathrm{~B}$ cells (unpublished data). As a result, we found that the anti-invasive effects of DLE and DRE are mediated through the inhibition of FAK and src activity. To the best of our knowledge this is the first study reporting the anti-invasive activity of extracts of Taraxacum species and especially of TO. The exact reason for the reduction in invasion can not be explained at present, as many of the known components in the roots and leaves can contribute to the observed effect (27-29) and this also depends on the composition of the extracts of the studied species.

Further fractionation and isolation of the active ingredients in the individual extracts will be crucial for elucidating: i) the anti-proliferative effect of DLE on MCF-7/AZ cells as well as ii) the differential effect of DRE and DLE on the invasive behavior of MCF-7/AZ and LNCaP C4-2B cells.

Medicinal plants, originating from or related to TCM, play an important role in the treatment of cancer and represent a valuable source for the discovery of small molecule inhibitors targeting signal transduction proteins, e.g. kinases, that modulate proliferation and invasion of cancer cells. Examples of such components derived from TCM include indirubin, inhibiting cyclin-dependent kinases, and emodin influencing a variety of signaling molecules among them, FAK and the PI3K-Cdc42/Rac1 pathway (30-32).

In summary, our data demonstrate that the aqueous extracts of different parts of TO inhibit cell proliferation and invasion and illustrate the importance of validating the use of traditional medicinal plants and herbs in therapy. Furthermore, these results indicate that DLE and DRE contain active compounds, which may be used in the development of new agents to combat cancer.

\section{Acknowledgements}

This work is supported by the US National Institutes of Health (RR-16480) under the BRIN/INBRE program of the National Center for Research Resources and the New Mexico Tech startup funds.

\section{References}

1. Frawley D and Lad V: The Yoga of Herbs. 2nd edition. Lotus Press, 2001.

2. Foster S and Johnson R: Desk Reference to Nature's Medicine. National Geographic Society, 2006.

3. Sweeney B, Vora M, Ulbricht C and Basch E: Evidence-based systematic review of dandelion (Taraxacum officinale) by natural standard research collaboration. J Herb Pharmacother 5: 79-93, 2005.

4. Blumenthal M: The complete German Commission E monographs: therapeutic guide to herbal medicines. American Botanical Council, Austin, 1998.

5. Takasaki M, Konoshima T, Tokuda H, Masuda K, Arai Y, Shiojima $\mathrm{K}$ and Ageta $\mathrm{H}$ : Anti-carcinogenic activity of Taraxacum plant I. Biol Pharm Bull 22: 602-605, 1999.

6. Takasaki M, Konoshima T, Tokuda H, Masuda K, Arai Y, Shiojima K and Ageta $\mathrm{H}$ : Anti-carcinogenic activity of Taraxacum plant II. Biol Pharm Bull 22: 606-610, 1999.

7. Choi JH, Shin KM, Kim NY, Hong JP, Lee YS, Kim HJ, Park HJ and Lee KT: Taraxinic acid, a hydrolysate of sesquiterpene lactone glycoside from the Taraxacum coreanum NAKAI, induces the differentiation of human acute promyelocytic leukemia HL-60 cells. Biol Pharm Bull 25: 1446-1450, 2002.

8. Hata K, Ishikawa K, Hori K and Konishi T: Differentiationinducing activity of lupeol, a lupine-type triterpene from Chinese dandelion root (Hokouei-kon), on a mouse melanoma cell line. Biol Pharm Bull 23: 962-967, 2000.

9. Koo HN, Hong SH, Song BK, Kim CH, Yoo YH and Kim HM: Taraxacum officinale induces cytotoxicity through TNF-alpha and IL-1alpha secretion in Hep G2 cells. Life Sci 74: 1149-1157, 2004. 
10. Romijn JC, Verkoelen CF and Schroeder FH: Application of the MTT assay to human prostate cancer cell lines in vitro: establishment of test conditions and assessment of hormonestimulated growth and drug-induced cytostatic and cytotoxic effects. Prostate 12: 99-110, 1988

11. Bracke ME, Van Larebeke NA, Vyncke BM and Mareel MM: Retinoic acid modulates both invasion and plasma membrane ruffling of MCF7 human mammary carcinoma cells in vitro. Br J Cancer 63: 867-872, 1991.

12. Thalmann GN, Anezinis PE, Chang SM, Zhau HE, Kim EE, Hopwood VL, Pathak S, von Eschenbach AC and Chung LW: Androgen-independent cancer progression and bone metastasis in the LNCaP model of human prostate cancer. Cancer Res 54: 2577-2581, 1994

13. Thalmann GN, Sikes RA, Wu TT, Degeorges A, Chang SM, Ozen M, Pathak S and Chung LW: LNCaP progression model of human prostate cancer: androgen-independence and osseous metastasis. Prostate 44: 91-103, 2000.

14. Skehan P, Stroeng R, Scudiero D, Monks A, McMahon J, Vistica D, Warren JT, Bokesch H, Kenney S and Boyd MR: New colorimetric cytotoxicity assay for anticancer drug screening. J Natl Cancer Inst 82: 1107-1112, 1990.

15. Steelant WF, Goeman JL, Philippe J, Oomen LC, Hilkens J, Krzewinski-Recchi M-A, Huet G, Van der Eycken J, Delannoy P, Bruyneel EA and Mareel MM: Alkyl-lysophospholipid 1-Ooctadecyl-2-O-methyl-glycerophosphocholine induces invasion through episialin-mediated neutralization of E-cadherin in human mammary MCF-7 cells in vitro. Int J Cancer 92: 527-536, 2001.

16. Bracke ME, Boterberg T, Bruyneel EA and Mareel MM: Collagen invasion assay. In: Metastasis Research Protocols. Brooks S and Schumacher U (eds). Humana Press, Totowa, pp81-89, 2001.

17. Brown PD, Levy AT, Margulies IM, Liotta LA and StetlerStevenson WG: Independent expression and cellular processing of $\mathrm{Mr} 72,000$ type IV collagenase and interstitial collagenase in human tumorigenic cell lines. Cancer Res 50: 6184-6191, 1990 .

18. Newmann DJ and Cragg GM: Natural products as sources of new drugs over the last 25 years. J Nat Prod 70: 461-477, 2007.

19. Sriram D, Yogeeswari P, Thirumurugan R and Bal TR: Camptothecin and its analogues: a review on their chemotherapeutic potential. Nat Prod Res 19: 393-412, 2005.
20. Huang KC: The Pharmacology of Chinese Herbs. 2nd edition. CRC Press, Boca Raton, 1999.

21. Zhang CH, Mei XG, Liu L and Yu LJ: Enhanced paclitaxel production induced by the combination of elicitors in cell suspension cultures of Taxus chinensis. Biotechnol Lett 22: 1561-1564, 2000.

22. Roberts PJ and Der CJ: Targeting the Raf-MEK-ERK mitogenactivated protein kinase cascade for the treatment of cancer. Oncogene 26: 3291-3310, 2007.

23. Schutz K, Carle R and Schieber A: Taraxacum: a review on its phytochemical and pharmacological profile. J Ethnopharmacol 107: 313-323, 2006

24. Lambert JD, Hong J, Yang GY, Liao J and Yang CS: Inhibition of carcinogenesis by polyphenols: evidence from laboratory investigations. Am J Clin Nutr 81: 284-291, 2005.

25. John A and Tuszynski G: The role of matrix metalloproteinases in tumor angiogenesis and tumor metastasis. Pathol Oncol Res 7: 14-23, 2001.

26. Van Slambrouck S and Steelant WFA: Clustering of monosialylGb5 initiates downstream signalling events leading to invasion of MCF-7 breast cancer cells. Biochem J 401: 689-699, 2007.

27. Jin UH, Lee JY, Kang SK, Kim JK, Park WH, KIM JG, Moon SK and KIM CH: A phenolic compound, 5-caffeoylquinic acid (chlorogenic acid), is a new type and strong matrix metalloproteinase-9 inhibitor: isolation and identification from methanol extract of Euonymus alatus. Life Sci 77: 2760-2769, 2005.

28. Lansky EP, Harrison G, Froom JP and Jiang WG: Pomegranate (Punica granatum) pure chemicals show possible synergistic inhibition of human PC-3 prostate cancer cell invasion across Matrigel. Invest New Drugs 23: 121-122, 2005.

29. Ovesna Z, Vachalkova A and Horvathova K: Taraxasterol and beta-sitosterol: new naturally compounds with chemoprotective/ chemopreventive effects. Neoplasma 51: 407-414, 2004.

30. Eisenbrand G, Hippe F, Jakobs S and Muehlbeyer S: Molecular mechanisms of indirubin and its derivatives: novel anticancer molecules with their origin in traditional Chinese phytomedicine. J Cancer Res Clin Oncol 130: 627-635, 2004.

31. Huang Q, Shen HM and Ong CN: Emodin inhibits tumor cell migration through suppression of the phosphatidylinositol 3-kinase-Cdc42/Rac1 pathway. Cell Mol Life Sci 62: 1167-1175, 2005.

32. Huang Q, Shen HM, Shui G, Wenk MR and Ong CN: Emodin inhibits tumor cell adhesion through disruption of the membrane lipid Raft-associated integrin signaling pathway. Cancer Res 66: 5807-5815, 2006. 